\title{
BLOG COMO FERRAMENTA PARA DISCUTIR LIMITES DA MANIPULAÇÃO DE IMAGENS NA PUBLICIDADE
}

\author{
Aline Pivetta Maia ${ }^{1}$, Igor Andrei C. Mafaldo ${ }^{1}$, Inaê Barbosa Ramos ${ }^{1}$ \\ Vanessa dos Anjos Baptista ${ }^{1}$, Janea Kessler ${ }^{2}$ \\ ${ }^{1}$ Publicitário(a) - Centro Universitário Franciscano - UNIFRA, Santa Maria, RS. \\ aline.kuka@hotmail.com \\ igormafaldo@hotmail.com, \\ ei.nae@hotmail.com, \\ nessadosanjos@hotmail.com, \\ 2 Profa. Orientadora - Centro Universitário Franciscano - UNIFRA Santa Maria, RS. \\ janeaki@terra.com.br
}

\section{RESUMO}

Com a evolução dos meios de manipulação de imagens, seu recorrente uso, e o grande impacto que isto causa na publicidade, ligados a importância da linguagem não verbal em anúncios publicitários, uma discussão tornou-se imprescindível. Devido a isso viemos através de este experimento gerar discussão sobre o mesmo. Com isso, o trabalho teve como objetivo analisar a partir de um blog voltado para profissionais de propaganda e estudantes da área o julgamento dos mesmos a respeito do uso constante que a publicidade faz do uso de manipulação de imagem. Pois a internet é um meio rápido, fácil, e de grande acesso para obtermos as respostas desejadas para este experimento.

Palavras-chave: Publicidade, blog, imagem, manipulação.

\section{ABSTRACT}

With the evolution of media manipulation, his recurring use, and this causes great impact on advertising related to the importance of nonverbal language in advertisements, a discussion has become indispensable. Because of this came across this experiment to generate discussion on it. Thus, the study aimed to analyze from a blog aimed at professionals and students in the area advertising the trial of the same about the constant use that advertising makes use of image manipulation. Because the Internet is a fast, easy, and great access to obtain the desired responses for this experiment.

Keywords: Advertising, blog, image, manipulation.

\section{INTRODUÇÃO}

As imagens têm grande importância para a publicidade. A manipulação exagerada em imagens tem preocupado muitos setores da sociedade, tanto que encontramos uma proposição de Lei Federal de autoria do deputado Wladimir Costa (PMDB-PA), em análise na Câmara dos Deputados, na qual consta: 


\section{Monografias Ambientais}

"toda imagem publicitária que tenha sido modificada com o intuito de alterar características físicas de pessoas retratadas traga, obrigatoriamente uma frase de alerta: Atenção: imagem retocada para alterar a aparência física da pessoa retratada" (CCSP, 2010).

Considerando-se a importância conferida às imagens pelo uso publicitário, e da notícia da proposição de lei, acreditamos que seria pertinente questionar a prática de manipulação de imagens, e seus limites de utilização.

A imagem é linguagem não-verbal, icônica, impactante e representativa e é um dos pilares da mensagem publicitária. Segundo Hora (2007), a imagem publicitária atualmente conta com os dispositivos digitais como aliados de seus produtores, pois a velocidade possibilitada pelas ferramentas digitais permite alterações de cores, texturas, luminosidade e outras características estéticas com muita qualidade técnica.

Junto à evolução das técnicas e meios de reprodução gráfica, houve mudanças nas imagens utilizadas e distribuídas pela publicidade; ao observar historicamente as imagens produzidas em anúncios percebemos que estas vêm sofrendo transformações no ponto de vista estético e de composição.

Portanto, há questões éticas com relação ao uso de imagem na publicidade, que não possuem ênfase necessária de discussão. As leis, notícias e curiosidades que têm o uso da imagem publicidade como foco não possuem um ambiente virtual que permita interação social, onde possa haver trocas de informações, manifestação de opiniões. Neto (2003), afirma que com o desenvolvimento dos ambientes da realidade virtual, pode-se pensar em inteligência coletiva, onde a troca de informações é, em sua essência, virtual.

Gandelman (2004) afirma que a publicidade é uma área de conhecimento que recorre à interatividade digital, portanto, o objetivo deste projeto foi criar um blog voltado a profissionais da propaganda e estudantes da área, de forma que os mesmos pudessem discutir e ser informados acerca de leis, normas, notícias que cercam o ambiente profissional do meio a respeito do uso de imagens manipuladas.

Sabendo das diversas possibilidades de interação oferecidas pela internet, e de que aliada a estas possibilidades está a busca cada vez maior de seus usuários por troca de informação e experiências, escolhemos o blog como um meio de comunicação e interação, capaz de expressar e atingir nossos objetivos.

Então, criamos o blog "Lei do Exagero", sob sítio eletrônico http://leidoexagero.com/. Nele reunimos, além da proposição de lei PL-6853/2010, do deputado Wladimir Costa, informações sobre legislação vigente, curiosidades e notícias divulgadas na imprensa que envolvem o uso da imagem em peças publicitárias, para promover discussão sobre o excesso de manipulação em imagens.

Divulgamos o endereço do blog através de e-mail para os profissionais de propaganda e alunos da área, instigamos profissionais de propaganda e alunos da área a acessar o blog e comentar sua posição sobre o assunto e averiguamos, por meio do blog, as opiniões de profissionais e estudantes de publicidade sobre o uso de imagens manipuladas.

Assim, realizado o experimento, pudemos analisar opiniões do públio-alvo sobre a criação da lei, popularmente já chamada de "lei do Photoshop", e sobre manipulação em imagens publicitárias e em editoriais. 


\title{
FUNDAMENTAÇÃO TEÓRICA
}

\author{
IMAGEM E MANIPULAÇÃO
}

A representação do real através de imagens tem cumprido um papel fundamental na vida do ser humano desde seus primórdios, como é atestado por desenhos, marcas, símbolos e pinturas pré-históricas encontradas em cavernas. As imagens têm cumprido diferentes papéis importantes na sociedade, tanto na representação gráfica utilizada como registro para posterior recordação, ou mesmo na manifestação artística, servindo para representar sentimentos que raramente conseguem ser expressos por palavras.

$O$ advento das tecnologias da informação trouxe poderosas ferramentas para tratamento de imagens, além de fornecer a capacidade de criação de novas possibilidades visuais. Conforme Woods (2007), já na década de 90, cientistas e artistas brasileiros começaram a se interessar pela área de processamento de imagens por computador. E então a área e manipulação de imagens através de meios digitais tornou-se cada vez mais popular, e útil para diversas áreas, como na publicidade, por exemplo.

Segundo Sant'Anna (2002), a publicidade utiliza-se da imagem porque esta possibilita a memorização do anúncio e contribui para a identificação do produto e também para criar diferenciação em relação aos produtos concorrentes. A imagem pode trazer a memorização do produto ou marca pelo consumidor, favorecendo associações de idéias, como por exemplo, o resultado da utilização de um produto. Para o autor,

a ilustração é, sobretudo, um estímulo sutil e forte, de ordem emotiva, que tende a desencadear os desejos e os interesses, que são as molas da ação, e a estimular a imaginação (SANT'ANNA, 2002, p.181).

Acredita-se assim, que os publicitários utilizam imagens (às vezes exageradamente manipuladas) para criar um cenário que faça do produto um sonho, um desejo, algo que o transformará o produto impecável para o consumidor, assim como é apresentado na imagem. Imagina-se que os anúncios se "convertam em uma realização estética, pois quanto mais atraente for o produto, mais as pessoas desejarão adquiri-lo e menor será o intervalo entre a data em que sai da fábrica e aquela em que é vendido" (FONTES, 2000, p.7).

Com o intuito de estimular o desejo pelo produto anunciado, antes da fotografia publicitária ser feita, ela é pensada e preparada, desde o cenário escolhido, como o enquadramento e escolha da luz a ser utilizada. Porém, a fotografia, depois de feita, pode contar com alguns ajustes, o que tem se mostrado corriqueiro em anúncios publicitários.

Com a criação da fotografia digital e consequentemente dos programas de edição de imagens na computação gráfica, estas ficaram mais fáceis de serem trabalhadas, aumentando o potencial de manipulação. O uso de tratamento de imagens tornou-se muito freqüente e não apenas pela publicidade, mas também pelo cinema e pelo jornalismo, por exemplo.

Segundo Santaella e Noth (1997), é possível manipular a fotografia alterando o objeto referencial na imagem e proporcionando aos observadores uma ilusão de um objeto que não existe. Desde os primórdios da história da fotografia, este potencial foi reconhecido e utilizado em técnicas, como a filtragem de cores, solarização, dupla exposição, fotomontagem e retoques.

Para Samain (2005), diferentemente das fotografias convencionais, a imagem eletrônica é muito mais manipulável. Os dispositivos tecnológicos tornam-se grandes aliados da publicidade, pois permitem que qualquer imagem possa ser profundamente alterada. Comumente se vê o 
apuramento de cores e definições de tons e iluminação nas imagens publicitárias, mas muitas vezes estas são manipuladas radicalmente, alterando drasticamente alguns elementos de sua composição.

São questionáveis os limites éticos da utilização da manipulação radical de imagens pela publicidade. Gomes (2006), por exemplo, afirma que todo anúncio publicitário é uma forma de inserção na sociedade, e que as responsabilidades éticas dos publicitários são grandes. Ela afirma que no caso das campanhas publicitárias

\begin{abstract}
é possível estabelecer as responsabilidades da agência e do anunciante, pois enquanto a primeira deve se ater ao processo de elaboração e difusão do conteúdo, o segundo responde pelas informação e pela aprovação que alimentaram os procedimentos publicitários. Mas a textura ética dos conteúdos não é exclusiva do publicitário (agência) ou anunciante, e sim uma composição híbrida formada por momentos e interesses específicos identificados pela relação agência (publicitário) e anunciante (profissional ou executivo) (GOMES, 2006, p. 47).
\end{abstract}

Portanto, a responsabilidade pelo uso de manipulação exagerada de imagens provoca uma discussão que engloba normas éticas para publicitários e anunciantes. Porém a manipulação de imagens não é algo novo, pois já era realizada há muito temo no campo das artes.

No surrealismo, por exemplo, as imagens que eram baseadas em sentimentos, fantasias e ilusões, não buscavam representar a realidade tal como ela é. Artistas como Salvador Dali, sonhavam e interpretavam em suas obras a realidade como a imaginavam. As obras do período traziam a forte característica da justaposição de imagens, colagens, gravuras e desenhos. Segundo Meggs (1998), as imagens "brincavam" e procuravam novas regras de estruturação, que fugissem da lei da gravidade e criassem uma realidade-ficção, uma verdade-ilusão.

Outro movimento que utilizava-se da manipulação de imagens era o Dadaísmo. Conforme Meggs (1998), a filosofia do movimento era a liberdade em seu sentido mais amplo: liberdade de expressão, liberdade de ação e liberdade de crença. As características dadaístas de expressar-se de forma a causar um forte impacto, produzia imagens constantemente manipuladas ou sobrepostas, causando efeitos e tratamentos inusitados.

A fotografia também foi uma manifestação artística que surgiu como forma de expressão na história das artes. Segundo Braune (2000), fotógrafos pictorialistas realizavam fotomontagens baseadas na perfeição de detalhes das pinturas pré-rafaelistas, o que afastava as fotografias do real, mas criava a intervenção direta do artista na obra, ou seja, a autoria.

Portanto, constata-se que a manipulação em imagens não é algo novo. A história mostra que a manipulação ocorria até mesmo como manifestação artística. A publicidade, como um modelo de comunicação apresenta a de manipulação em imagens como uma atrativa e instigante forma de seduzir o consumidor.

\title{
LEIS, NORMAS E PUBLICIDADE
}

As agências de publicidade, os anunciantes, os fornecedores e veículos de comunicação, ao longo de anos passaram por diversas transformações dentro do cenário brasileiro e mundial. Assim também vale afirmar que "a publicidade hoje é um complexo e sofisticado negócio financeiro" (JAPIASSU, 2010, p.1). 
Dentro de todo contexto da evolução histórica da publicidade no Brasil, vale ressaltar dois momentos importantes para a profissionalização e a responsabilidades das agências e profissionais da propaganda no país "a criação da ABP, Associação Brasileira de Propaganda, em julho de 1937, para defender os interesses das agencias, mercado e sociedade perante a indústria das comunicações. E a criação da ABAP, Associação das Agencias de Publicidade e Propaganda, dez anos depois."(JAPIASSU, 2010, p.1)] A principal característica da Associação Brasileira de Propaganda (2010) é cuidar da preservação dos preceitos éticos na propaganda, defendendo os valores culturais do Brasil.

De acordo com Junior (2010), o CONAR é uma organização não-governamental, que se mantém pelas agências de publicidade, empresas anunciantes e veículos de comunicação e tem como função administrar a comunicação comercial levando em consideração o que estabelece o Código Brasileiro de Auto-regulamentação Publicitária em relação a práticas desejáveis na publicidade. O CONAR opera, também, como órgão judicante nas questões éticas relacionadas a publicidade ou sua indústria.

Visto que o CONAR reúne conjuntos de normas quanto à autorregulamentação, percebe-se a grande importância desta e do Código de Ética dos profissionais da propaganda, criado em 1957, para que as agências e profissionais da propaganda orientem-se e conscientizem-se acerca de suas responsabilidades éticas. O objetivo das normas estabelecidas pelo Conar é colaborar no esforço da sociedade em formar cidadãos responsáveis, consumidores conscientes e difundir hábitos de vida saudável.

Percebe-se a importância de alguns itens relevantes para o estudo proposto, já que podese afirmar a partir do documento do Código Brasileiro de Autorregulamentação Publicitária, Introdução, seção1 - Preâmbulo, Artigo 1ㅇ, que "todo anúncio deve ser respeitador e conformarse às leis do país; deve, ainda, ser honesto e verdadeiro".

Neste sentido, o anúncio deve respeitar a legislação brasileira em vigor e obedecer as normas sociais estabelecidas. Além disso, o Código Brasileiro de Auto-regulamentação Publicitária prescreve outras regras, que pretendem defender e esclarecer o consumidor. Desta forma, os produtos devem ser apresentados de maneira honesta e íntegra, permitindo ao consumidor uma visão verdadeira do produto.

Percebe-se que a publicidade transita em um cenário complexo, no qual pode-se questionar se toda peça publicitária veiculada obedece realmente a esta recomendação, quando exagera no uso de ferramentas de manipulação digital de imagem, publicando algo quase irreal.

O Artigo $5^{\circ}$ estabelece que "nenhum anúncio deve denegrir a atividade publicitária ou desmerecer a confiança do público nos serviços que a publicidade presta à economia como um todo e ao público em particular". Este artigo ressalta a importância dos anúncios não denegrirem e nem desmerecerem as atividades publicitárias, no sentido de não prejudicarem a credibilidade dos consumidores utilizando-se de argumentos falsos ou enganosos, por exemplo.

\section{Conforme o Artigo 17}




\section{Monografias Ambientais}

ao aferir a conformidade de uma campanha ou anúncio aos termos deste Código, o teste primordial deve ser o impacto provável do anúncio, como um todo, sobre aqueles que irão vê-lo ou ouvi-lo. A partir dessa análise global é que se examinará detalhadamente cada parte do conteúdo visual, verbal ou oral do anúncio, bem como a natureza do meio utilizado para sua veiculação.

Portanto, esta regulamentação garante aos consumidores uma publicidade mais fiel e honesta, maior reconhecimento da sociedade, assim como maior respeito e seriedade em relação aos anunciantes e aos veículos de comunicação.

Em relação ao Código de Ética dos Profissionais da Propaganda verifica-se também que "a ABP foi responsável pela elaboração do Código de Ética dos Profissionais de Propaganda, que teve um primeiro projeto elaborado em 1939, mas veio a ser realmente aprovado no primeiro congresso d'a classe, realizado no Rio de Janeiro, em outubro de 1957." (JAPIASSU, 2010, p.1)

Este parágrafo do documento do Código de Ética dos Profissionais da Propaganda ressalta que "o profissional da propaganda [...] jamais induzirá o povo ao erro, jamais lançará mão da inverdade; jamais disseminará a desonestidade e o vício", Parágrafo III, Introdução, Documento do Código de Ética.

\section{CIBERESPAÇO E INTERNET}

Dentre os meios de comunicação atuais cita-se a internet, que Saad (2003, p.22) define como "uma rede mundial de computadores interconectados que possibilita a troca de mensagens, dados e arquivos entre os usuários." Acredita-se que as pessoas busquem na internet conteúdo e relações virtuais de discussão acerca de afinidades e assuntos de interesse, expondo suas opiniões e gerando conteúdo.

A internet é mais que uma ferramenta de comunicação, mas identificamos como ideal para desenvolvermos este projeto, já que agrega um ambiente de comunicação digital, interativa dentro do chamado ciberespaço. O termo cyberspace ${ }^{1}$ se contextualiza em um mundo virtual onde se realizam trocas de informações entre as pessoas, e que de acordo com Silva (2000, p.17) "consiste em uma região abstrata invisível que permite a circulação de informações na forma de imagens, sons, textos, etc."

Seu conceito é ampliado por Lévy $(1999$, p.17) o qual afirma que ciberespaço é "[...] o novo meio de comunicação que surge da interconexão mundial de computadores". A evolução é extraordinariamente veloz, pois hoje as pessoas podem comunicar-se instantaneamente com outras pessoas que estão do outro lado do planeta, de maneira rápida e com um baixo custo. Para conectar-se, basta um computador e acesso a internet.

Pode-se ilustrar certa complexidade do assunto através deste trecho:

1 No que se refere a noção de ciberespaço, a terminologia vem de cyber, da "teoria da cibernética" desenvolvida no final da Segunda Guerra pelo matemático Norbert Wiener. Mais recentemente (1984), o termo "cyberspace" foi utilizado pelo escritor de fiç̧ão científica Willian Gibson em "Neuromancer". Para Gibson, o ciberespaço é um espaço não físico ou territorial, que se compõe de um conjunto de redes de computadores através das quais todas informações (sob variadas formas) circulam. A partir de Gibson este termo popularizou-se. 


\section{Monografias Ambientais}

Uma alucinação consensual vivida diariamente por bilhões de operadores autorizados, em todas as nações, por crianças aprendendo altos conceitos matemáticos... Uma representação gráfica de dados abstraídos dos bancos de dados de todos os computadores do sistema humano. Uma complexidade impensável. Linhas de luz abrangendo o não-espaço da mente; nebulosas e constelações infindáveis de dados. Como marés de luzes da cidade. (GIBSON, 2003, p. 67).

O ciberespaço então é dito como uma esfera da sociedade em rede, onde informações definem modernas formas de comunicação e relacionamento sociais. Ela trata de disseminar importantes informações entre emissores e os receptores.

Tratando-se da linguagem científica entende-se o ciberespaço como sinônimo de internet, entretanto, é visto de outra maneira por Jungblut $(2004$, p.102) que ressalta "[...] a internet, se primarmos por um rigorismo conceitual, é apenas a base material [...] é apenas uma rede de computadores, de máquinas interligadas."

Acredita-se que a cibercultura faz parte das mais atuais formas tecnológicas de comunicação, as redes online, entrelaçadas à comunicação. Segundo Lévy (2003, p.17) "o ciberespaço é o novo meio de comunicação que surge da interconexão mundial dos computadores. Não apenas a infra-estutura material da comunicação digital, mas também as informações que abriga." A cibercultura é o conjunto de técnicas, práticas, atitudes, modos de pensamento e valores que se desenvolvem com o crescimento do ciberespaço.

O conceito de cibercultura está atrelado ao processo tecno-social da cultura contemporânea onde as tecnologias de comunicação e informação estão transformando práticas sociais, formas de produção e consumo midiáticas, o entretenimento, a educação e a economia neste começo de século XXI. (LEMOS, 2003, p.151.)

Contudo, para Lemos (2003, p.12), um dos pioneiros em pesquisa sobre o tema no Brasil, a cibercultura deve ser entendida "como a forma sócio-cultural que emerge da relação simbiótica entre a sociedade, a cultura e as novas tecnologias de base micro-eletrônica que surgiram com as convergências das telecomunicações com a informática, na década de 70". A partir destes conceitos acredita-se que a interatividade digital, surge como uma forma de interação, de troca de informações existentes na web, é uma construção dentro da esfera cibernética.

A interatividade digital é uma relação técnico-social e possibilita ao usuário interagir não só com o objeto, mas também com a informação. Com a web, a interação é de todos os usuários concomitantemente com todos os usuários. Esta relação evolui no sentido da superação das barreiras físicas entre os homens e máquinas, para uma crescente interação do usuário com a informação (WACHOWICZ, 2006, p.54.)

Galdeman (2004, p.121), ressalta que "atualmente, a interatividade digital é uma prática comum em diversas áreas, como escritórios virtuais, telebanking, comércio eletrônico, publicidade e marketing interativo, TV interativa, games e etc." Pois com a comunicação que a internet possibilita de forma instantânea entre emissores e receptores de mensagens, consegue-se agregar diferentes valores e atributos aos serviços disponíveis online que usam as possibilidades que o meio oferece para trazer diferentes experiências e interação com o consumidor.

\section{BLOGS}

A internet proporciona novas ferramentas sociais, novos instrumentos e plataformas para a comunicação. Segundo Recuero (2009), a comunicação utilizando-se do computador, mais do 


\section{Monografias Ambientais}

que permitir aos indivíduos comunicarem-se, amplificou a capacidade de conexão, permitindo que redes fossem criadas e expressas nesses espaços: as redes sociais mediadas pelo computador.

Podemos citar como algumas dessas ferramentas os blogs, que hoje, por sua importância e pelo grande número de pessoas que possuem, garantem uma grande troca de informações entre os internautas. Segundo Schittine (2004, p. 13), "o blog surgiu como um sistema de disponibilização de textos e fotos na web menos complexo e mais rápido, o que facilitou a fabricação de páginas por indivíduos com pouco conhecimento técnico."

De acordo com Hewitt (2007, p. 47), o primeiro blog surgiu em 1999. Após cinco anos, em 2004, esse número havia aumentado para 4 milhões. Existem milhões de blogs, e a cada dia são criados ainda mais. Destes, muitos são criados e abandonados, mas a maioria é mantida por pelo menos alguns meses.

Em seu processo evolutivo, os blogs têm sido usados como um poderoso instrumento e expressão pessoal e de escrita colaborativa, seja a partir de sites individuais, o que é o mais comum na web, seja e forma coletiva, em blogs escritos por vários autores ao mesmo tempo. Todos desfrutam a possibilidade de, através de recursos de links e comentários participar de comunidades de interesse na web, dando vitalidade a essa mais recente, veloz e transformadora interface social. (SILVA, 2006, p. 336).

Hewitt (2007) afirma que a blogosfera ${ }^{2}$ está evoluindo a um ritmo muito acelerado e adquirindo um grande número de leitores. Entretanto, centenas de milhões de pessoas ainda precisam olhar além da e perceber que há um acesso mais rápido, mais específico e mais satisfatório à informação. Os blogs são feitos de velocidade e confiança, e isso mantém a blogosfera, enquanto a mídia tradicional é lenta demais e tem confiança de menos.

Já Schittine (2004) ressalta, quanto ao sistema de comentários, que o blog abre espaço para que várias pessoas escrevam, é democrático, e quando abre para um maior número de pessoas, mais segmenta do que generaliza.

É possível realizar um diálogo não apenas entre os comentaristas, mas também com o autor do blog. Trata-se de uma interação construída, negociada e criativa. É possível observar-se em um blog não apenas a interação em um comentário, mas a relação entre várias interações e perceber-se que tipo de relação transpira através daquelas trocas (RECUERO, 2009, p. 33).

Blog é uma palavra que vem da abreviação de weblog - web (tecido, teia, também usada para designar o ambiente de Internet) e blog (diário de bordo, registro). É um diário on-line que permite que os usuários registrem diversos conteúdos, é composto por blocos de textos e imagens, que são apresentados em uma mesma página, e ficam disponíveis em uma ordem cronológica. Orduña (2007) apresenta o que entende por blog:

Weblogs e blogs são páginas pessoais da web que, à semelhança de diário on-line, tornaram possíveis a todos publicar na rede. Por ser a publicação on-line, centralizada no usuário e nos conteúdos, e não na programação ou no design gráfico, os blogs multiplicaram o leque de opções dos internautas de levar para a rede conteúdos próprios

2 um ambiente informativo no qual se reproduzem os pressupostos, as condições e os resultados do mundo plurárquico. (URGATE, 2008, p.37) 
sem intermediários, atualizados e de grande visibilidade para os pesquisadores. (ORDUÑA, 2007, p.50).

O blog é um importante instrumento de comunicação, interação e compartilhamento de idéias, informações e conhecimentos de forma colaborativa, com a vantagem de que possibilita um espaço para comentários dos leitores, como afirma Orduña (2007, p.65) "a relação entre leitor e autor de um blog pode ser entendida como um pacto de leitura: um acordo implícito entre ambos, por meios do qual se medem expectativas do leitor quanto ao texto", e por estas características, torna-se uma importante ferramenta que pode ser explorada potencialmente inclusive na área educacional.

Em princípio é um meio pessoal, que funciona sem fins lucrativos, sem prazos, e que é escrito, em geral, pelo prazer de compartilhar informações ou como veículo de expressão. Também "o blog possui uma resposta mais rápida, mais impressionista e mais pessoal do que os meios de comunicação tradicionais e, por sua vez, contribui para ampliar as fronteiras da realidade mediática." (ORDUÑA, 2007, p.74)

Pode-se identificar características principais de um blog: a interatividade, por exemplo, que se dá através dos comentários que outras pessoas podem deixar, dizendo suas opiniões, dando sugestões, interagindo com o mesmo e a hipertextualidade, que se caracteriza pela metamorfose e constante mutação destas páginas. Outra característica básica de um blog, como meio de comunicação

É que ele consegue fazer que o processo de publicação na rede seja quase completamente transparente e praticamente simultânea à escrita. Essas características se traduzem na informalidade, na espontaneidade e no caráter pessoal, às vezes íntimo, do estimulo dominante nos blogs. (ORDUÑA, 2007, p. 41)

Como uma nova ferramenta de comunicação, um blog deve ser criativo, inovador, deve prender a atenção das pessoas que estão lendo, o autor deve tornar as condições das escritas claras, contribuindo assim para a segurança de sua relação com os leitores, tornando uma página consolidada e de credibilidade.

Segundo Mercado (2008), o blog é uma publicação online ou que envolve a exposição pessoal na internet e se caracteriza pela configuração cronológica inversa das entradas que ocorrem diariamente e buscam conexões, notícias e opiniões informais e subjetivas, de autoria individual na maioria das vezes.

Querido e Ene (2003) definem o blog como um diário em formato eletrônico e interativo, pois recebem comentários os leitores. Pode ser criado rapidamente e gratuitamente por qualquer pessoa que possua acesso à internet. O blog é definido pelos arquivos, que comportam as entradas do blog, e os comentários. Para os autores, este diário eletrônico apresenta outra característica que o difere de antigas páginas pessoais: a interatividade, a partir de comentários dos leitores, que emitem opiniões pessoais, sendo este um de seus principais atrativos.

De acordo com Flynn (2006), um novo blog é criado a cada segundo, pois consiste em uma ferramenta de comunicação muito útil para milhões de indivíduos que possuem uma convicção e anseiam compartilhá-la. Milhares de empresas que procuram uma maneira eficaz para construir relacionamentos de confiança com clientes, assim como jornalistas que desafiam a grande mídia e oferecem uma fonte alternativa de notícias trabalham incessantemente com essa ferramenta.

Segundo Flynn (2006) e Bly (2007), apesar de 62\% dos utilizadores da Internet não saberem o que é um blog, este tornou muito popular e ganhou destaque no Brasil em 2004. No mesmo 
ano, a revista americana BusinessWeek relatou o crescimento explosivo dos blogs e o dicionário de pesquisas online Merrian-Webster anunciou que o blog foi a palavra solicitada com maior frequência. A revista americana Time publica uma lista anual dos 50 melhores blogs.

Bly (2007) afirma que oito milhões de adultos americanos tinham blogs, um de cada quatro usuários de internet liam blogs, e 12 por cento dos utilizadores da Internet postavam comentários em blogs.

E complementando

Alguns bloggeiros acreditam que o blog é uma revolução da Internet, e que por este motivo a comunicação convencional se tornará obsoleta. Alguns ironicamente se referem a livros, revistas e jornais como mídia antiquada, árvores mortas, e estão convencidos de que o blog vai se tornar a mais poderosa forma de marketing e mídia do planeta (Bly, 2007).

Sendo assim a qualidade e as informações postadas em um determinado blog devem ser adequadas, assim como toda campanha de comunicação, ao seu público-alvo. Pois um blog é uma maneira interativa e de facil acesso, tornando acessível a comunicação entre quem escreve e quem irá ler.

\section{METODOLOGIA}

Metodologia é a forma utilizada para definir as etapas a serem seguidas num determinado processo: "entende-se [metodologia] como um caminho que se traça para se atingir um objeto qualquer. É, portanto, a forma, o modo para resolver problemas e buscar respostas para as necessidades e dúvidas." (MICHEL, 2009, p. 35). Complementando, Miranda (2008, p.1) afirma que "na escolha do método devemos ter sempre em conta os resultados que advirão da sua escolha e utilização, na medida em que estes nos aproximam ou afastam da realidade a estudar."

Nosso projeto experimental foi a criação de um blog, contendo informações e curiosidades sobre o uso de imagens manipuladas no meio publicitário e editorial. Essa plataforma digital foi baseada no projeto de lei $6853 / 10$, o qual poderá fazer com que toda a imagem publicitária manipulada digitalmente traga obrigatoriamente uma frase de advertência. $O$ estudo foi de natureza exploratória, que visa para Michel (apud GIL, 1993, p. 45) "proporcionar maior familiaridade com o problema, com vistas a torná-lo mais explícito ou a construir hipóteses. Podese dizer que estas pesquisas têm como objetivo principal o aprimoramento de idéias ou a descoberta de intuições"

Este estudo teve uma análise qualitativa, pois analisamos as opiniões de profissionais e estudantes da área de publicidade que postaram no blog sobre o que eles acham sobre imagens tratadas ou não e uma pesquisa quantitativa também foi feita para mensurar a quantidade de acessos que foram feitos, através dos comentários deixados. Michel $(2009$, p.36) afirma que "pesquisa qualitativa, o pesquisador participa, compreende e interpreta" e uma análise quantitativa, "o pesquisador descreve, explica e prediz".

O método ou "ferramenta" para a resolução do presente trabalho foi o experimental que "consiste em experimentar, fazer experiências. Fato, fenômeno, processo da realidade que é 
produzido de forma controlada, com objetivo de descobrir os fatores que o produzem ou que por ele seja produzido." Tognetti (2006, p.21). No caso deste estudo, testamos o blog como ferramenta para discussão do tema manipulação excessiva de imagens na publicidade e na mídia.

A justificativa para a do presente trabalho foi por causa da criação do blog, onde foram analisadas quais as opiniões das pessoas sobre as informações postadas, através de comentários deixados por elas na página.

O universo visado foi profissionais e estudantes da área de publicidade, por se tratar de um projeto onde abordamos as leis, informações e curiosidades sobre o uso de imagem manipulada no meio publicitário.

\section{O PRODUTO}

Foi criado para a disciplina de projeto experimental, um blog destinado à profissionais da área de Publicidade e Propaganda e acadêmicos desse curso. O site ficou hospedado no endereço eletrônico: http://www.leidoexagero.com.

O objetivo da criação deste blog foi para informar e gerar discussão a respeito do exagero na manipulação de imagens, e também para informar sobre a possibilidade da aprovação de uma nova lei que esta em tramite na Câmara dos Deputados Federais sobre o uso do Photoshop em anúncios publicitários.

\section{OPERACIONALIZAÇÃO}

Para a realização do blog, primeiramente foram pesquisados sites que oferecessem blogs pré-prontos gratuitamente. Estes ofereciam hospedagem de blogs em endereços que pudéssemos escolher o nome, com "domínio.net". Estes sites possibilitavam a escolha de alguns layouts prédeterminados. O conteúdo destes sites permitia que em cada post houvesse comentários. Também era possível colocar informações sobre o usuário dono do blog, neste caso sobre o projeto.

Porém, depois da procura o grupo chegou à conclusão que estes não supriam as necessidades desejadas. Pois seria fundamental para a realização do projeto que soubéssemos informações acerca do nosso universo pesquisado. Precisávamos de dados das pessoas que efetuassem comentários, como ocupação (estudante, profissional da área ou outros), instituição ou empresa (agências ou fornecedores) e e-mail. Além destas informações gostaríamos que fossem registrados dados como nome, sexo, idade ou outras atividades exercidas pelos respondentes, que não fossem as relacionadas à publicidade.

Como a primeira opção não correspondia as nossas necessidades passamos a procurar outras empresas que oferecessem serviços digitais, fornecendo assim o que estávamos desejando. Buscamos orçamento com duas agências de publicidade digitais santa-marienses no período entre 03 a 04 de setembro de 2010, com o intuito de criar um site, que seria com o layout parecido com a de um blog, para conter informações de quem éramos e qual era o objetivo do nosso projeto. Foram contatadas as empresas Fullwizz e Pactacom, com a qual fechamos contrato na data 06 de setembro de 2010.

Esta empresa forneceu melhores condições, prazo e valor para desenvolver um site com todas as ferramentas que desejávamos, pois deveria constar um espaço que submetessem aos 
visitantes a responder uma ficha de inscrição para então assim podermos saber quem foram às pessoas que acessaram e comentaram o blog.

Solicitamos então, á Pactacom, após fecharmos um contrato de $\mathrm{R} \$ 145,00$, instruções de como almejávamos os detalhes do site, com a idéia de ser o layout referenciando a interface do Photoshop, pois o assunto do blog é a manipulação de imagens na publicidade, e este é um dos softwares mais utilizados para este fim. Também foi definido o nome e consecutivo domínio do site. O site foi hospedado no endereço ".com", ao invés do ".com.br", por este ser mais barato. Sendo o nome escolhido pelo grupo: Lei do exagero, fazendo alusão ao assunto proposto pelo projeto.

No blog deveria haver uma barra de menus com quatro links. O primeiro deste seria a pagina inicial (anexo 1), trazendo um breve texto explicando o motivo da idealização do projeto, e também fotografias em miniatura de cada um dos posts, encaminhando estas aos textos a serem comentados. O segundo item da barra de menus traria o blog na integra, com os posts em ordem cronológica de postagem (anexo 2). O terceiro ícone traria a definição e a justificativa do projeto (anexo 3). No quarto e último item seria disponibilizado um formulário para preenchimento caso os visitantes desejassem entrar em contato com o grupo (anexo 4).

A intenção destas especificações no blog era proporcionar interatividade, característica apresentada por Querido e Ene (2003) na página 12, parágrafo terceiro, da fundamentação teórica.

Como o site teria um prazo determinado para ficar no ar, foi definido que seriam postados em uma única vez, para que os visitantes escolhessem quais deles gostariam de comentar. Definimos a quantidade de nove postagens para o blog, pois essa quantidade permitiria abordarmos os assuntos desejados a cerca do tema do blog.

Após isso, os membros do grupo ficaram responsáveis por criar os posts. Estes deveriam instigar nosso universo a opinar, deixando no blog seus comentários sobre se concordava ou não com o assunto tratado, como afirma Recuero (2009) na última citação da página 10, da fundamentação teórica.

Duas postagens deveriam abordar o tema de exagero na manipulação de imagens em editoriais. Outro deveria trazer um cruzamento de informações sobre as leis e normas publicitárias referentes ao tema e a lei motivadora do projeto. Os outros seis posts deveriam exemplificar com anúncios publicitários as manipulações exageradas ou conseqüências das mesmas para a publicidade. Todos os posts colocados no site deveriam indagar as pessoas, e analisar se elas concordavam ou não com a notícia mostrada, expondo assim seu ponto de vista.

Como se trata de um trabalho acadêmico, todos os posts tinham textos criados pelos integrantes do grupo, com a notícia referente ao texto em cima e contendo a fonte de onde foi retirada a matéria mostrada, deixando assim os posts mais longos e com um caráter acadêmico, diferente de como apresentam os textos expostos na maioria dos blogs existentes, que são com textos muito resumidos e de fácil leitura, como exposto na página 11 , referente ao autor Orduña (2007) quarto parágrafo.

A elaboração dos posts perdurou desde a assinatura do contrato, até a revisão final dos mesmos. O blog foi ao ar dia 10 de outubro, mas foi disponibilizado ao público somente no dia 15 de outubro, devido aos ajustes necessários, como detalhes de layout, formulário, links e textos, ficando no ar até o dia 15 de novembro. 
A DIVULGAÇÃO

Para atingirmos o objetivo proposto inicialmente, de obter comentários do público-alvo, precisávamos divulgá-lo. Ao pensarmos a necessidade da colaboração dos coordenadores de outras instituições para que alunos e professores participassem da discussão no blog, pesquisamos e percebemos que o contato com eles seria fundamental para o bom andamento do trabalho. Então buscamos uma lista com todas as instituições de ensino do estado do Rio Grande do Sul (que ofertavam o curso de Publicidade e Propaganda), e contatos como telefones e e-mail dos coordenadores, para então podermos mandar o convite a alunos e professores a acessarem 0 nosso blog.

Os e-mails de profissionais utilizados para divulgação foram encontrados com contatos pessoais dos integrantes do grupo, assim como contatos profissionais de amigos e conhecidos de pessoas próximas. Um levantamento de agências do estado buscou contatos de e-mail nos endereços eletrônicos dos mesmos.

Com o intuito de promover acessos, foram realizadas as seguintes etapas: produção de um webcard (anexo 5), ofício a ser destinado aos coordenadores dos cursos de publicidade de universidades do estado (anexo 6), divulgação através de site de relacionamento (anexo 7) e visitas as salas de aula, do curso de publicidade e propaganda da Unifra, dias 29 de outubro, 10 e 3 de novembro de 2010, com o objetivo de incentivar o acesso dos alunos.

O webcard foi a forma mais rápida e objetiva encontrada, para comunicarmos com o universo desejado. Este foi enviado por e-mail aos coordenadores, juntamente com um ofício. Para os profissionais da área enviamos apenas o webcard, por e-mail. A divulgação via site de relacionamentos deu-se apenas com o envio do webcard, por scrap, para isto, foi criado um perfil no Orkut com 130 alunos e profissionais de publicidade.

Produzimos um oficio assinado pela coordenadora e pela orientadora explicando quem éramos, qual a importância e o universo a ser estudado e por ultimo solicitando que eles contribuíssem com o projeto, enviando nosso webcard ao mailing de alunos e professores daquela instituição de ensino.

Nossa coordenadora Cristina Jobim entregou o ofício pessoalmente a coordenadores em um evento, no dia 10 de outubro, solicitando apoio deles para com nosso projeto experimental. Os coordenadores de curso de publicidade que receberam o ofício pessoalmente, foram: Alessandro, da ESPM; Luciano, da Faculdade Cenecista de Bento Gonçalves; Juliana Peterman, da UFSM; Ania, da Unisinos; Cristiano, da Feevale; Fabiana, da Unisc; Marcelo da UCS; Ilton, da Famecos e Vera, da Faccat.

Para reforçar a divulgação, este ofício foi enviado por e-mail junto ao webcard, dia 25 de outubro para os emails dos coordenadores de todas as instituições que ofereciam o curso de Publicidade e Propaganda.

\section{RESULTADOS}

Passado um mês da disponibilização do blog, obtivemos os comentários necessários, não o número desejado, mas o suficiente para assim termos noção do que as pessoas acham sobre a manipulação de imagem na publicidade, se concordam ou não.

Após todo trabalho realizado, por tratar-se de comentários livres e abertos acerca de cada questionamento que os posts traziam tornou-se difícil interpretar se cada pessoa concordava ou 
descordava daquele questionamento, pois uma boa parte dos comentários foi feito de uma maneira geral a respeito do assunto abordado pelo nosso blog, e não comentários diferentes a cada posts como o desejado pelo grupo.

Como o objetivo de nosso blog era saber a opinião de nosso universo, fizemos as seguintes perguntas dentro dos seguintes posts, no nosso site;

Post Atecendentes (anexo 8):

Pergunta: "Será que o alerta serviria para esclarecer melhor aos consumidores sobre o que é ou não prejudicial a sua saúde? Os instrumentos reguladores da publicidade não estariam mais preocupados com a questão? A lei serviria para auxiliar o Código de defesa do consumidor e o Código Brasileiro de Autorregulamentação Publicitária?"

Resposta 1 de Fernanda Buera, profissional da área que trabalha na Arcor Dr. Otker, distribuidora Dismaria.

Creio que não será uma lei que vai contribuir para a diminuição dos transtornos alimentares, isso vem do psicológico de cada um. Assim como a lei seca, fica na consciência de cada pessoa saber que não se deve beber e dirigir. Ver um corpo magro em uma campanha e querer ser igual também tem suas conseqüências.

Reposta 2 de Edilaine Avila, estudante de Publicidade e Propaganda da Unifra.

Acredito que a proposta é válida, mas não terá muito impacto na sociedade. A maioria das pessoas já sabe que as fotos normalmente sofrem tratamento estético, escrever isto no anúncio apenas vai confirmar isso, mas não trará grandes mudanças aos consumidores. Com exceção, claro, das pessoas com escolaridade baixa, que não distinguem muito bem este tipo de atividade. Entretanto, afirmar que as fotos são tratadas não irá tirar o brilho da publicidade bem feita, apenas ela deixará de causar tanta empolgação nas pessoas.

As duas pessoas respondentes discordam que a lei pode trazer mudanças no comportamento dos consumidores, principalmente no que se refere ao consumo e impacto causado pelos anúncios publicitários. Mas nenhuma das duas responde as outras duas perguntas propostas, fazendo com que não obtivéssemos as respostas desejadas para o restante da pergunta.

Post Beleza natural e manipulada (anexo 9)

Pergunta: "Será que a iniciativa desta marca de biquínis incentivará outras grifes a valorizar a beleza natural das mulheres? Após a revelação de todas as manipulações realizadas nesta imagem, questiona-se: seriam necessárias todas estas alterações na silhueta da modelo? Poderíamos minimizar o uso do Photoshop diante de uma sociedade onde tudo é medido pela estética?"

Resposta 1 de Leandro estudante de Publicidade e Propaganda da PUCRS.

Acredito que esta empresa só tem a perder, pois enquanto outras empresas estampam mulheres perfeitas em seus anúncios, esta marca vende seu produto atrelado a uma mulher normal. Com certeza uma imagem com Photoshop desperta muito mais interesse de compra. 
Resposta 2 de André Cecim estudante de Publicidade e Propaganda da Unifra.

\begin{abstract}
Eu vejo a iniciativa dessa empresa como muito boa, pois apesar de vivermos em uma época de culto ao corpo, as pessoas estão cientes de que as imagens das mulheres que estampam normalmente os anúncios não representam a realidade. Essa é uma grande barreira que a publicidade busca transpor, pois o exagero de "retoque" nos anúncios é um dos motivos da propaganda ser vista como enganosa. E iniciativas como a dessa empresa, podem ser o ponto de partida para uma mudança no pensamento das pessoas, o que refletirá futuramente em uma publicidade muito mais transparente e verdadeira.
\end{abstract}

Nas respostas obtidas, os respondentes discordam entre si. Sendo um a favor da atitude da empresa, achando que irá vender mais usando deste método, e que estratégias como a desta empresa podem tornar a publicidade mais confiável para os consumidores; o outro contra discorda totalmente desta resposta, acreditando que essa atitude só irá fazer a empresa perder, pois imagens manipuladas segundo ele despertam mais interesse de compra.

Post Corpos esculpidos pelo Photoshop (anexo 10)

Pergunta: Será que ambas as revistas venderiam menos com retoques mais sutis nas atrizes? Resposta 1 de Maiani, estudante de Publicidade e Propaganda da Unifra.

Eu acho que venderiam até mais com menos retoques, pois se torna até sem graça abrir uma revista e ver a perfeição dos corpos das famosas sabendo que é Photoshop. Queremos ver mais a realidade, que se igualem à pessoas "normais", assim nos identificaremos.

Resposta 2 de Daniela Veeck, estudante de Publicidade e Propaganda da Unifra.

Acho extremamente necessário a criação desta lei. É claro que nós Publicitários devemos seduzir o consumidor. No entanto estamos criando uma sociedade onde os padrões de beleza e busca pelo corpo perfeito (onde essa perfeição é pura manipulação midiática) leva Brasil a ser o terceiro lugar em cirurgias plásticas estéticas, devemos realmente repensar se estes exageros estão corretos.

Resposta 3 de Leandro, estudante de Publicidade e Propaganda da PUCRS.

Na minha opinião as revistas venderiam menos pois mulheres não comprariam revistas como Boa Forma para receberem dicas de mulheres "normais" e homens não comprariam revistas masculinas para ver mulheres iguais as que tem em casa, quem gastaria dinheiro para ver e receber dicas de pessoas comuns? Com qual finalidade?

Resposta 4 de Mauricio Riendolff Dotto, estudante da UFSM. 


\title{
Monografias Ambientais
}

(Revista Eletrônica do Curso de Especialização em Educação Ambiental da UFSM)

Acredito que na sociedade em que vivemos onde tudo gira em torno de um lucro e do faturamento de empresas, para gerarem riqueza para o país e fazer o capital girar, penso que fará diferença sim, pois quem consome este tipo de informação são pessoas ignorantes perante a sociedade, que só visam uma satisfação material e própria e que são manipuladas pelo sistema capitalista, porém chegamos ao ápice. É tanta propaganda onde tudo que é segmento de comunicação, que a falta do Photoshop na mulher da capa da revista causaria um espanto, pois leitores daquela revista fútil estranhariam muito se realmente aquela mulher cheia de imperfeições seria realmente real. Já que estão tão acostumados em mulheres visualmente perfeitas, sem o famosinho Photoshop elas talvez nem fossem reconhecidas e ou idolatradas, assim não havendo a venda do produto, pois o mercado já manipulou tanto a mente do povo que este, já não se identificaria mais com aquela imperfeição, já que elas (pessoas) também não são perfeitas e não se aceitam mais do jeito que são. Por isto há uma crescentes acerca das doenças da sociedade contemporânea, a Depressão, a Cobiça, a Inveja e o Individualismo gerado pelas próprias empresas que vendem uma vida perfeita e que deixa as pessoas sem cultura (educação, conhecimento) tão infelizes com a vida que levam. por isto a depressão, o auto índice de suicídios e assassinatos, fora seqüestros, bulling etc... Então acredito que a revista venderia menos, pelo fato de estar com menos retoques de Photoshop

\section{Resposta 5 de Samuel Cechin, estudante de Publicidade e Propaganda da Unifra.}

\begin{abstract}
A sociedade sempre viveu baseada nos estereótipos de beleza física e de ornamentos para destacar ainda mais o corpo. Os chamados "símbolos sexuais" são pessoas que são adotadas como exemplos de beleza. A décadas atrás o padrão destes símbolos sexuais eram as pessoas obesas, mas com a chegada da indústria "Hollywoodiana" o estereótipos que se estabelece, é de corpos musculosos e magros, e que permeia-se até hoje. Já a maquiagem e a tatuagem, também não são algo novo, no Egito na época dos faraós, ja eram aplicadas. Então, uma mídia, empresa, ou até mesmo um publicitário, alterar, com o uso de programas, quase que completamente o corpo ou tirar "marcas", como a tatuagem da modelo a cima, eles estão mexendo com uma cultura que poderia ser valorizada, pois tatuagem é Arte e também uma técnica milenar, e quanto ao corpo da modelo, quando eles fazem alterações deixando a pele destas totalmente modificadas (deixo bem claro que é minha opinião, nao estou criticando ninguém), estas pessoas parecem mais bonecos de cera doque pessoas, e pra mim isso fica muito artificial, e não agrada mais aos olhos, cada um tem sua beleza, a revista poderia até vender menos, mas apenas nas primeiras vezes, pois a Publicidade, tem o dom da palavra, se tiveram o poder de fazer a "massa" gostar de "bonecos" podem voltar a fazer, gostarem de pessoas.
\end{abstract}

Resposta 6 de Jonathan Mendes, formado pela UFSM.

Acredito que seja necessário analisar a influencia que a mídia irá repercutir socialmente e financeiramente. Nossa sociedade não mascara apenas modelos de revistas, mascara também a personalidade de pessoas e a corrupção. O photoshop apenas facilitou a aceitabilidade de uma sociedade critica que nesse momento defronta-se até mesmo com o sistema de correção das imperfeições. Uma modelo que era até então esculpida a photoshop, com a lei buscará " $n$ " maneiras da perfeição "natural" para evitar a frase no rodapé na revista aonde aparece. Com relação a Lei, acredito ser uma boa iniciativa ao realismo, ao combate a ilusão e a criticidade, as pessoas estão muito materialistas, está na hora da democracia eleger a humanização, despertar outras curvas, outras expressões e sentidos nas imagens e letreiros. Muitos preferem um vilão bonito a uma pessoa boa e 


\title{
Monografias Ambientais
}

REMOA

(Revista Eletrônica do Curso de Especialização em Educação Ambiental da UFSM)

feia. Quem sabe assim, não combateremos os excessos tratando-se de gordo, magro, alto, baixo, negro, branco, amarelo ou pardo. Coloque-se no lugar dessas pessoas que sabem que nunca irão ser que nem as pessoas de uma capa de revista, por mais que usem " $n$ " produtos por ali oferecidos. A publicidade não terá problemas afinal a criatividade é a alma do negócio, todos sabem. Será irá haver uma saída, uma alternativa. O desafio já começou! Sem dúvida haverá uma mudança na sociedade, o realismo aflorará, isso não tem nada a ver com proibir o photoshop ainda, se fosse talvez gerasse diretamente uma turbulência, mas desse modo acredito que não. Agora a lei é para ser cumprida, espero que a fiscalização e as multas sejam severas, afinal tem muitas revistas e editoras que tem cacife para bancar o sistema, até mesmo as modelos e patrocinadores.

Resposta 7 de lara, profissional da área.

\begin{abstract}
Não acho legal esses exageros do photoshop, cria uma falsa idéia de corpo perfeito, estimulando cada vez mais as pessoas buscarem essa perfeição que não existe. Acredito que as revistas não venderiam menos e que deveriam mostrar a "realidade"do corpo das famosas, as quais são pessoas "normais", que se esforçam e se frustram como todas as pessoas.
\end{abstract}

Ao observar os comentários, percebeu-se que de maneira geral, a maioria concorda com o questionamento, pois causaria espanto, sendo ás vezes necessário os retoques, mas poderiam buscar tratar com mais sutileza. Já aquelas que discordam, o fazem em partes. Apenas uma pessoa discorda completamente que a revista venderia menos, dizendo esta que se torna, segundo ela, "sem graça", uma pessoa totalmente modificada, sabendo que é Photoshop. Para a pergunta, duas pessoas responderam de forma geral, comentando sobre o tema. Para um dos respondentes, a lei incentivará o realismo nas imagens manipuladas, gerando um boa repercussão da lei.

Post Anos 60, com frases de alerta (anexo 11)

Pergunta: Ao deparar-se com o anúncio abaixo, questiona-se a que tipo de engano os consumidores poderiam ser expostos? Será que a consumidora que tiver contato com este anúncio teria dúvidas quanto à composição e finalidade do produto anunciado (Natura Chronos)? Qual seria a utilidade da frase "Atenção: imagem retocada para alterar a aparência física da pessoa retratada."?

Resposta 1 de Kellen Toller, estudante de Publicidade e Propaganda da Unipampa.

Acho essa lei desnecessária. Vai de cada anúnciante manipular ou não a imagem, e também vai de cada consumidor acreditar naquilo que está vendo. Nessa imagem, se colocada a imagem real, não haveria o consumo do produto, então que não apareça imagem nenhuma.

Resposta 2 de Angela, professora da Unifra.

Se for aprovada, acredito que lei terá algum efeito no receptor sim. Talvez, ao ler a advertência, as pessoas deixem de comprar produtos de beleza que prometam rejuvenescimento e emagrecimento, por exemplo. Mas em outros casos, acredito que a advertência não faça muita diferença. 
Resposta 3 de Juliano, estudante de Publicidade e Propaganda da Unisinos.

\begin{abstract}
Ótima notícia, deveria ser padrão para todos os lugares do mundo essa lei. Afinal, não dá pra comprar gato por lebre. Imagina quanto não é gasto em produtos de beleza para atingir algo que "fulana" atingiu, mas no computador, ao invés de na vida real. Independentemente se ela é nova ou velha, mas sim com a realidade da situação. Pensamos ser possível com base no que vemos, sem sabermos que o que vemos não é real, e sim produzido no computador. O maior abalo, claro, ocorre com os que buscam a perfeição seguindo a mídia. A fulana teve filho e em 1 mês "secou" e está com os peitos em cima, aí a esposa do cara também vai querer "secar" em 1 mês, aí decide não dar leite pro filho pros peitos não caírem, e por aí vai. Não pense que todos são informados e sensatos, ainda mais no Brasil.
\end{abstract}

Resposta 4 de Marina, profissional da área, da agência Matriz.

Não acho que essa lei vai interferir no código de autoregulamentação, pois as consumidoras não são enganadas sobre a composição e finalidade do produto por causa do Photoshop.

Uma das respostas demonstra que o visitante do blog considera a lei desnecessária, as outras, em sua maioria acreditam que a lei pode ser eficaz, mas acham que não trará tanto impacto no consumidor, quanto o desejado. Um dos respondentes concorda plenamente com a lei, dizendo que não considera correto o consumidor ser ludibriado pelo anúncio, pois considera que esta lei possa fazer com que os anunciantes "manerem" na maneira com a qual expões seus produtos.

Post Beleza Real (anexo 12)

Pergunta:O que acontecerá com anúncios da categoria de cosméticos que ousarem usar estratégias deste tipo em suas campanhas?

Resposta 1 de Ivana, profissional da área, da agência Miradoor.

As marcas que resolverem copiar o que a Dove criou não vão ter êxito, porque essa frase vai acabar com o anúncio do que é "real".

Houve apenas um comentário sobre esse assunto, sendo este acha que se copiarem a mesma proposta da Dove, elas não irão ter êxito pelo fato da frase de alerta mudar a proposta do anúncio.

Post Na contramão do Photoshop (anexo 13)

Pergunta: Você acredita que se aprovado o Projeto de Lei ${ }^{\circ} 6853 / 10$ do deputado Wladimir Costa (PMDB-PA), as agências irão produzir anúncios com fotos reais de modelos e celebridades, sem usar o Photoshop para 'retoques' ou vão assumir a alteração, aceitando a frase ("Atenção: imagem retocada para alterar a aparência física da pessoa retratada.") que será obrigatória em todos anúncios publicitários onde a figura humana tenha sido 'manipulada'?.

Resposta 1 de Leandro, estudante de Publicidade e Propaganda da PUCRS. 


\section{Monografias Ambientais}

REMOA

(Revista Eletrônica do Curso de Especialização em Educação Ambiental da UFSM)

Acredito que irão adotar a frase e continuar usando fotos com photoshop pois ainda assim venderiam mais do que estampar fotos sem manipulação de imagem.

Resposta 2 de Jorge, estudante de Publicidade e Propaganda da UFSM.

Provavelmente irão colocar a frase. É 'menos feio' colocar isso do que meter as Melancias da vida sem retocar. Pelo menos assim ninguém sabe onde estão os defeitos! Tem que se garantir demais pra fazer o que a Luiza fez. Mas e tu, nobre produtora do blog, o que faria se tivesse que escolher: com ou sem photoshop?

Resposta 3 de Daiana Negri, estudante de Publicidade e Propaganda da Unifra.

Cada caso é um caso. Acredito que em campanhas nas quais não haja necessidade de aparição de pessoas esbeltas e perfeitas, as agências optarão por modelos com aparências "reais", afinal, nesses casos a melhor saída é a criatividade. Enquanto que em anúncios onde a beleza seja totalmente indispensável, usarão a indicação.

Resposta 4 de Raíssa, estudante de Publicidade e Propaganda da Unifra.

Acho devido a essa onda de usar 'gordinha' 'mulheres fora do padrão de beleza posto pela mídia' é a moda, é tendência, justamente para criticar o grande uso de photoshop nas imagens. Mas não acho que o programa deve parar de ser usado, isso prejudicaria a venda de muitos produtos.

Resposta 5 de lara, profissional da área.

Acredito que haverá dificuldade de aceitação tanto por parte das agências quanto por parte das famosas, que terão que exibir seus corpos tais como são "realmente", ou encarar a tarja "rotulando" a sua imagem. Devemos considerar que a grande maioria não tem a personalidade e a beleza natural da Luiza Brunet! Parabéns por trazer à discussão um tema tão polêmico e atual.

Resposta 6 de Franciele, estudante Publicidade e Propaganda Unifra.

Realmente, acredito que não irão parar de usar o programa, mas acho interessante a utilização do aviso do uso, principalmente para o pessoal mais jovem e também para os mais desinformados, que muitas vezes buscam um ideal de beleza que não é real.

Em sua maioria acreditam que mesmo usando a frase, as agencias não irão parar de usar o descontroladamente a manipulação. Os respondentes acham que essa frase não deixará de ser usada, mas que os anunciantes procurarão outras técnicas para não usá-la. 
Post Política do "não retoque" (anexo 14)

Pergunta: Qual sua opinião diante desse assunto, já que atualmente somos abordados por um ideal de beleza dentro de uma construção social criada através de um condicionamento mental fruto de mega tendências?

Não houve comentários válidos para essa pergunta.

Post Exageros ou descuidos (anexo 15)

Pergunta: Sabendo-se que o foco dos anúncios publicitários é associar benefícios aos produtos visando interagir com o receptor pela persuasão, pergunta-se: Qual o limite de utilização de métodos para manipulações em imagens?

Resposta 1 de Fernanda Souza, profissional da área

Nos estudantes de PP aprendemos ao longo do curso que devemos vender sonhos, desejos, necessidades. Ética e o bom senso deveriam servir como limite entre a realidade e a manipulação digital. Acredito que quando a arte digital é feita de forma criativa sem mascar a realidade de fato não é exagero.

A respondente afirma que é comum o uso da manipulação, mas que há maneiras de driblar com criatividade a manipulação sem cair limites éticos.

Post Aceitação de aparência (anexo 16)

Pergunta: Assim, tendo como referência esses dois exemplos, você acredita que esteja surgindo um mercado duradouro para modelos gordinhas?

Não obtivemos respostas.

\section{CONCLUSÃO}

A partir do trabalho realizado pode se dizer que apesar da grande influencia que a imagem possui no cenário publicitário contemporâneo, o exagero na manipulação de imagens e algo que gera muita discussão e controvérsia, seja por profissionais da área, estudantes ou ainda leigos no assunto.

Concluindo assim que apesar da divulgação com ênfase no meio online, foi muito pouca a colaboração de alunos já formados e de profissionais da área. Sendo observado que pelo prazo que ficou no ar, aliados a textos longos, e grande quantidade de posts, ainda sim o blog obteve uma quantidade relevante de respostas para que pudéssemos compreender opiniões do universo pesquisado.

Alguns colegas que olharam o blog relataram que acharam os textos muito longos em formato muito sério e acadêmico, fazendo com que o visitante ficasse desinteressado em lerem os textos na integra, ou pela pura falta de vontade dos mesmos em responder o formulário, mas não deixando assim de considerarem interessantes os assuntos abordados e o blog.

Com este experimento verificamos que um blog é sim um lugar ideal para provocar a discussão do tema proposto, porem obterá maiores resultados se através de diversos meios, e com um prazo maior de disponibilização ao público, em uma linguagem mais coloquial. 


\section{Monografias Ambientais}

REMOA

(Revista Eletrônica do Curso de Especialização em Educação Ambiental da UFSM)

\section{REFERÊNCIAS BIBLIOGRÁFICAS}

ABAP, Associação Brasileira de Agências de Publicidade, disponível em <http://webserver.4me.com.br/wwwroot/abap/> Acesso em 2/0/6/2010.

ABP, Associação Brasileira de Propaganda, disponível em <http://www.abp.com.br/sobreabp/index.asp> Acesso em 2/06/2010.

BRAUNE, Fernando. 0 surrealismo e a estética fotográfica. Rio de Janeiro: 7 letras, 2000.

CAMARA DOS DEPUTADOS, disponível em <http://www.camara.gov.br/internet/sileg/Prop_Detalhe.asp?id=467269> Acesso em 10/04/2010.

CENP, Conselho Executivo das Normas-Padrão, disponível em <http://www.cenp.com.br/> Acesso em 2/06/2010.

CONAR, Conselho de Autorregulamentação Publicitária, disponível em <http://www.conar.org.br/html/codigos/indexcodigoseanexo.htm> Acesso em 02/06/2010.

CCSP, Clube de Criação de São Paulo, disponível em <http://ccsp.com.br/ultimas/noticia.php?id=44828> Acesso em 30/03/2010.

DUARTE, B.; BARROS, J. Organizadores. Métodos e técnicas de pesquisa em comunicação. São Paulo, SP : Atlas , 2005.

FONTES, Martins. A linguagem da propaganda. 3a Ed. São Paulo: Editora: Martins Fontes, 2000.

GANDELMAN, Henrique. O que você precisa saber sobre direitos autorais. São Paulo: Editora Senac, 2004.

GIBSON, Willian. Neuromancer. São Paulo: Aleph, 2003.

GOMES, Neusa Demartini (org.). Fronteiras da publicidade : faces e disfarces da linguagem persuasiva. Porto Alegre, RS : Sulina, 2006.

HORA, Daniel da. Imagem e publicidade : artes plásticas, semiótica e tecnologia. Recife, CE : Bureau de Imagens, 2007.

JAPIASSU, Celso. Publicidade: da criatividade ao negócio financeiro. Disponível em http://www.umacoisaeoutra.com.br/marketing/bb.htm. Acesso em 31 de maio de 2010.

JOLY, Martine. Introdução à análise da imagem. Campinas, SP : Papirus, 2003.

JUNGBLUT, Airton Luiz. A heterogenia do mundo on-line: algumas reflexões sobre virtualização, comunicação mediada por computador e ciberespaço. Horiz. Antropol. V.10, n.21. Porto Alegre jan./jun. 2004. Disponível em: <http://www.scielo.br/scielo.php?script=sci_arttext\&pid=S0104-71832004000100005\&lng=pt\&nrm=isso> Acesso em: 27 mai. 2010.

LEMOS, André. Cibercultura. Tecnologia e vida social na cultura contemporânea. Porto Alegre: Editora Sulina, 2003.

LÉVY, Pierre. Cibercultura. São Paulo: Editora 34, 1999.

MERCADO, Luis Paulo Leopoldo (org.) Práticas de formação de professores. Maceió: Editora UFAL, 2008.

MICHEL, Maria Helena. Metodologia e pesquisa científica em ciências sociais: um guia prático para acompanhamento da disciplina e elaboração de trabalhos monográficos. Atlas. 2005.

MINAYO, M. C. Pesquisa social: teoria, método e criatividade. 5.ed. Rio de Janeiro: Vozes, 1996. 


\section{Monografias Ambientais}

REMOA

(Revista Eletrônica do Curso de Especialização em Educação Ambiental da UFSM)

MIRANDA; Bruno. Método Quantitativo versus Método Qualitativo. 2008. Disponível em: http://adrodomus.blogspot.com/2008/06/mtodo-quantitativo-versus-mtodo.html Acesso em: 1 de maio de 2010.

NETO, João Augusto Máttar. Metodologia científica na era da informática. São Paulo, SP : Saraiva, 2003.

ORDUÑA, Octavio I. Rojas. Blogs: revolucionando os meios de comunicação. Thomson Learning, 2007.

QUERIDO, Paulo; ENE, Luís. Blogs: Sociedade da informação. Portugal: Centro Atlantico, 2003.

RECUERO, Raquel. Redes sociais na internet. Porto Alegre: Editora Sulina, 2009.

SAAD CORRÊA, E. Estratégias para a mídia digital, internet, informação e comunicação. 1. ed. São Paulo: Editora Senac-SP, 2003.

SAMAIN, Eienne. O fotográfico: Volume 29 de Linguegem e Cultura. 2a Ed. São Paulo: Editora Senac, 2005

SANTAELLA, Lúcia; NÖTH, Winfreied. Imagem: cognição, semiótica, mídia. São Paulo: Editora liluminuras, 1997.

SANTOS, Edméia; SILVA, Marco. Avaliação de aprendizagem e educação online. São Paulo: Editora Loyola, 2006.

SANT'ANNA, Armando. Propaganda : teoria, técnica e prática. São Paulo, SP : Pioneira, 2002.

SCHITTINE, Denise. Blog: Comunicação e escrita íntima na internet. São Paulo: Editora Record, 2004.

SILVA, M. Sala de aula interativa. Rio de Janeiro: Quartet. 2000.

TOGNETTI, Marilza Aparecida Rodrigues. Metodologia da Pesquisa Científica. 2006 Disponível em <http://sbiweb.if.sc.usp.br/metodologia_pesquisa_cientifica.pdf>

Acesso em: 1 de maio de 2010.

WOODS Richard E; Rafael C. Gonzales. Processamento de imagens digitais. São Paulo, SP: Blucher, 2000.

WACHOWICZ, Marcos. Direito da propriedade intelectual: estudos em homenagem ao Pe. Bruno Jorge Hammes. São Paulo: Editora Jurua, 2006. 


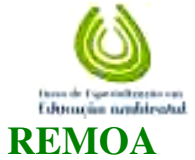

REMOA
MAIA et al., vol.(3), $\mathbf{n}^{\circ} 3$, p.482-513, 2011 Monografias Ambientais

(Revista Eletrônica do Curso de Especialização em Educação Ambiental da UFSM)

ANEXO 1 e 2
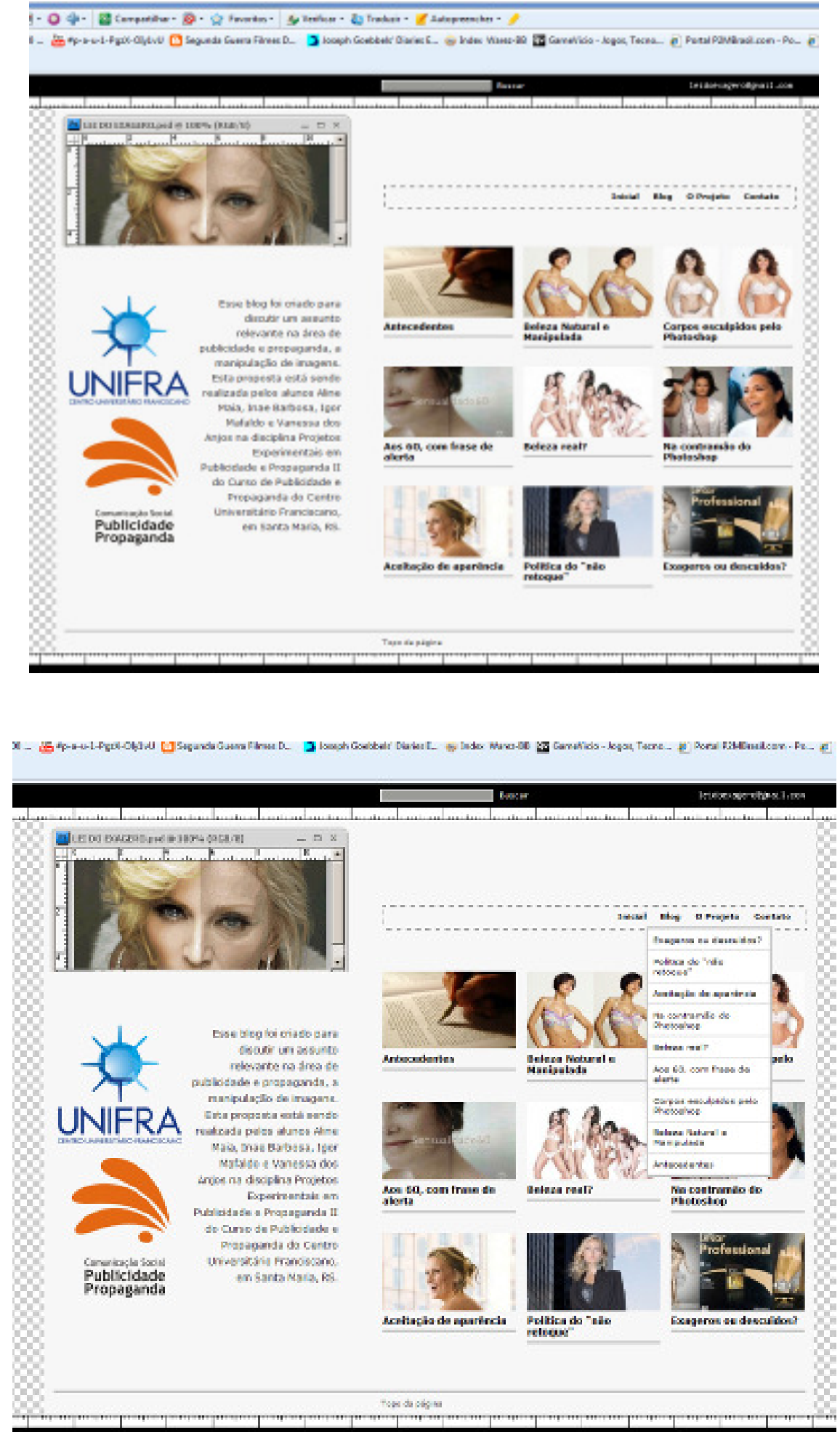


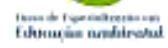

REMOA

\section{Monografias Ambientais}

(Revista Eletrônica do Curso de Especialização em Educação Ambiental da UFSM)

ANEXO 3 e 4
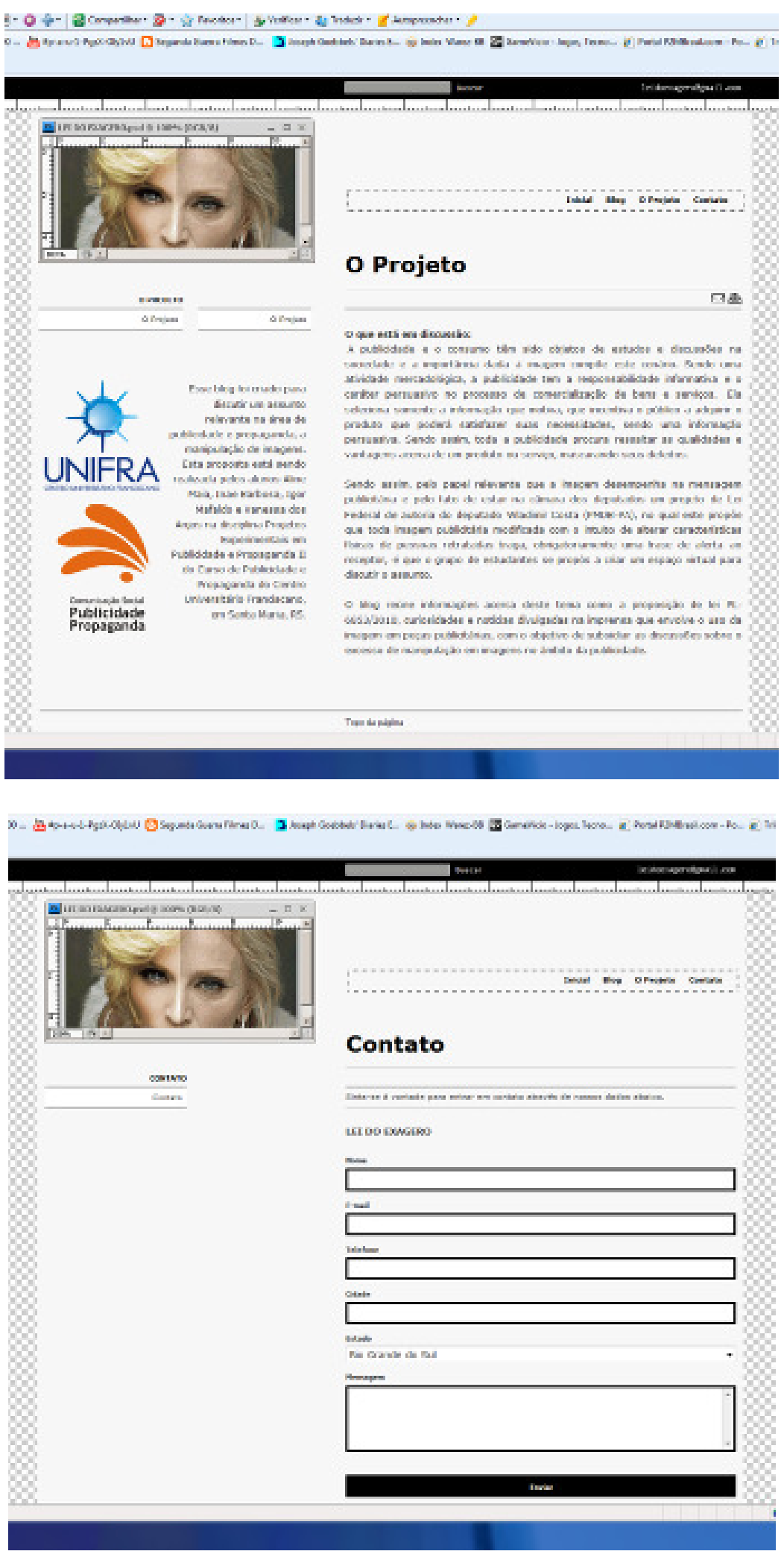
ANEXO 5 e 6
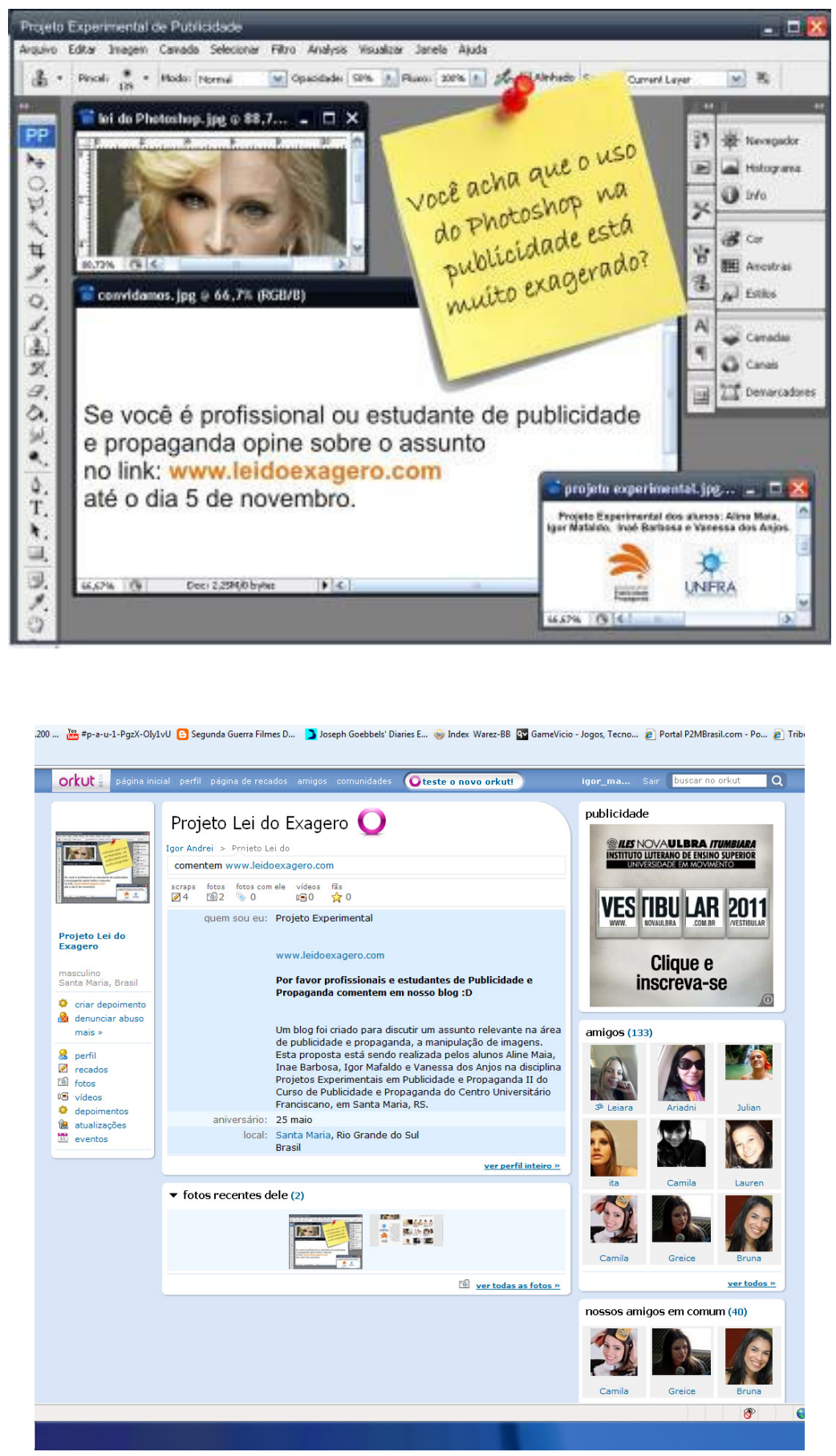


\section{Monografias Ambientais}

(Revista Eletrônica do Curso de Especialização em Educação Ambiental da UFSM)

Anexo 7 e 8
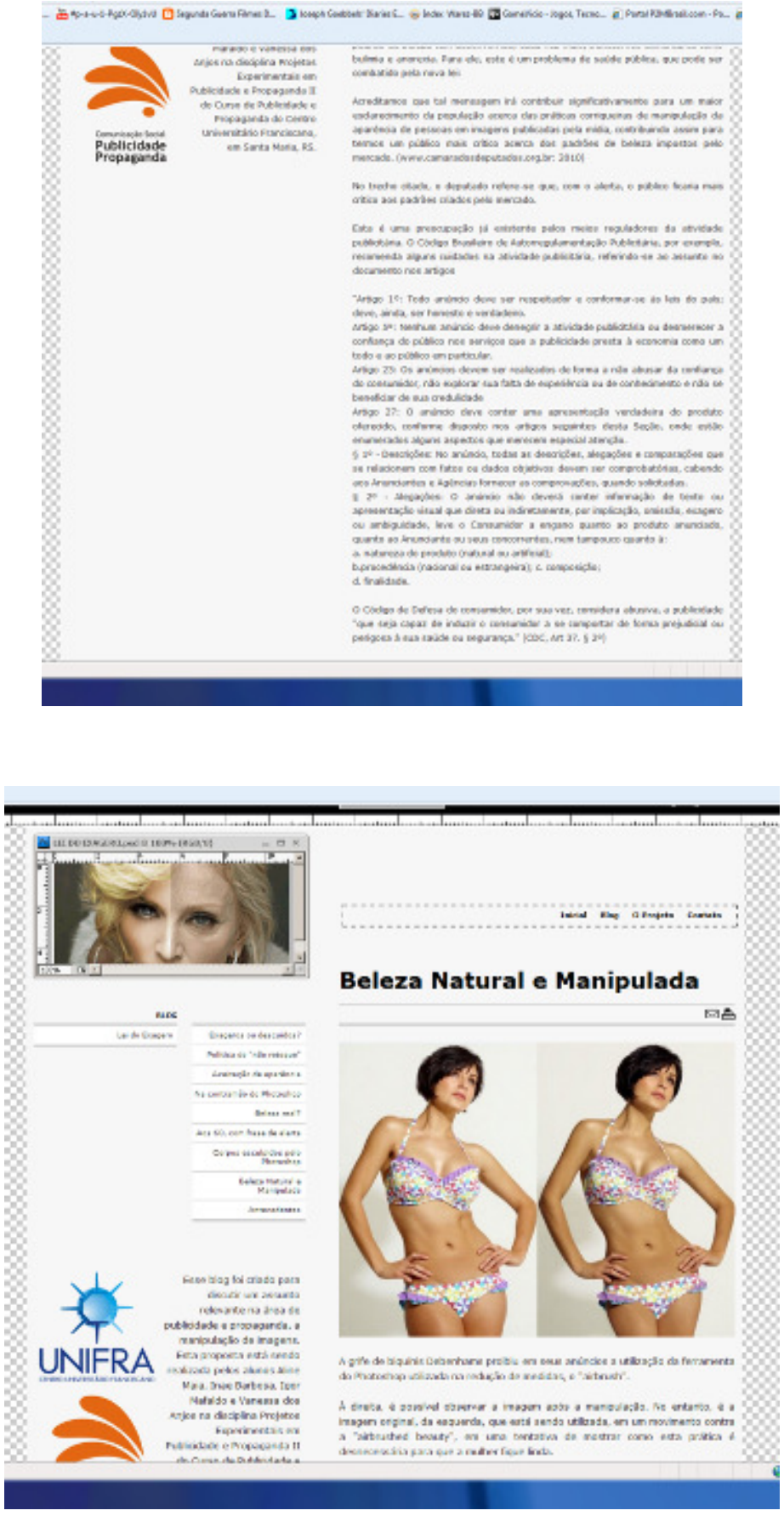


\section{Monografias Ambientais}

(Revista Eletrônica do Curso de Especialização em Educação Ambiental da UFSM)

Anexo 9 e 10
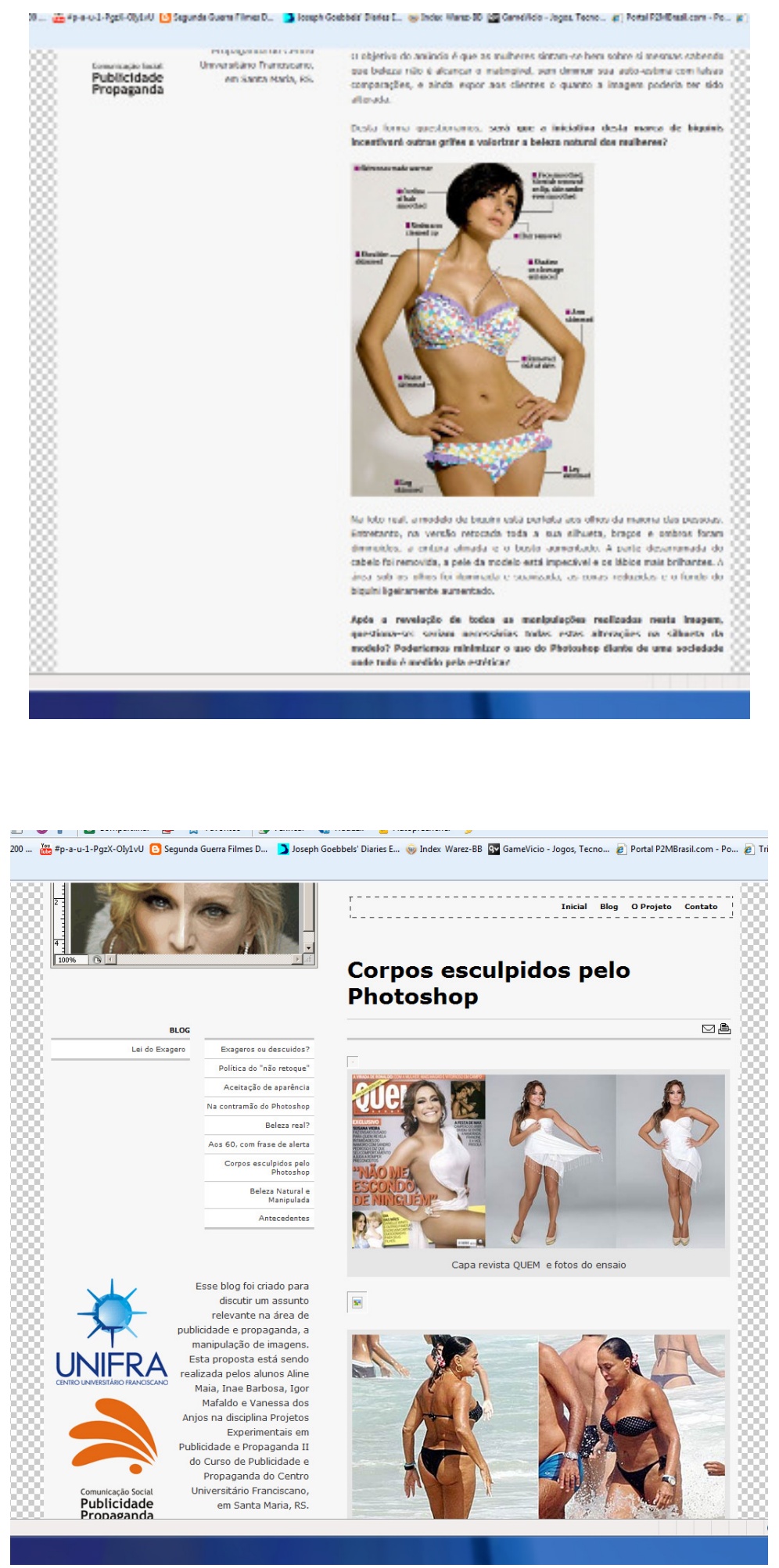
Anexo 11 e 12
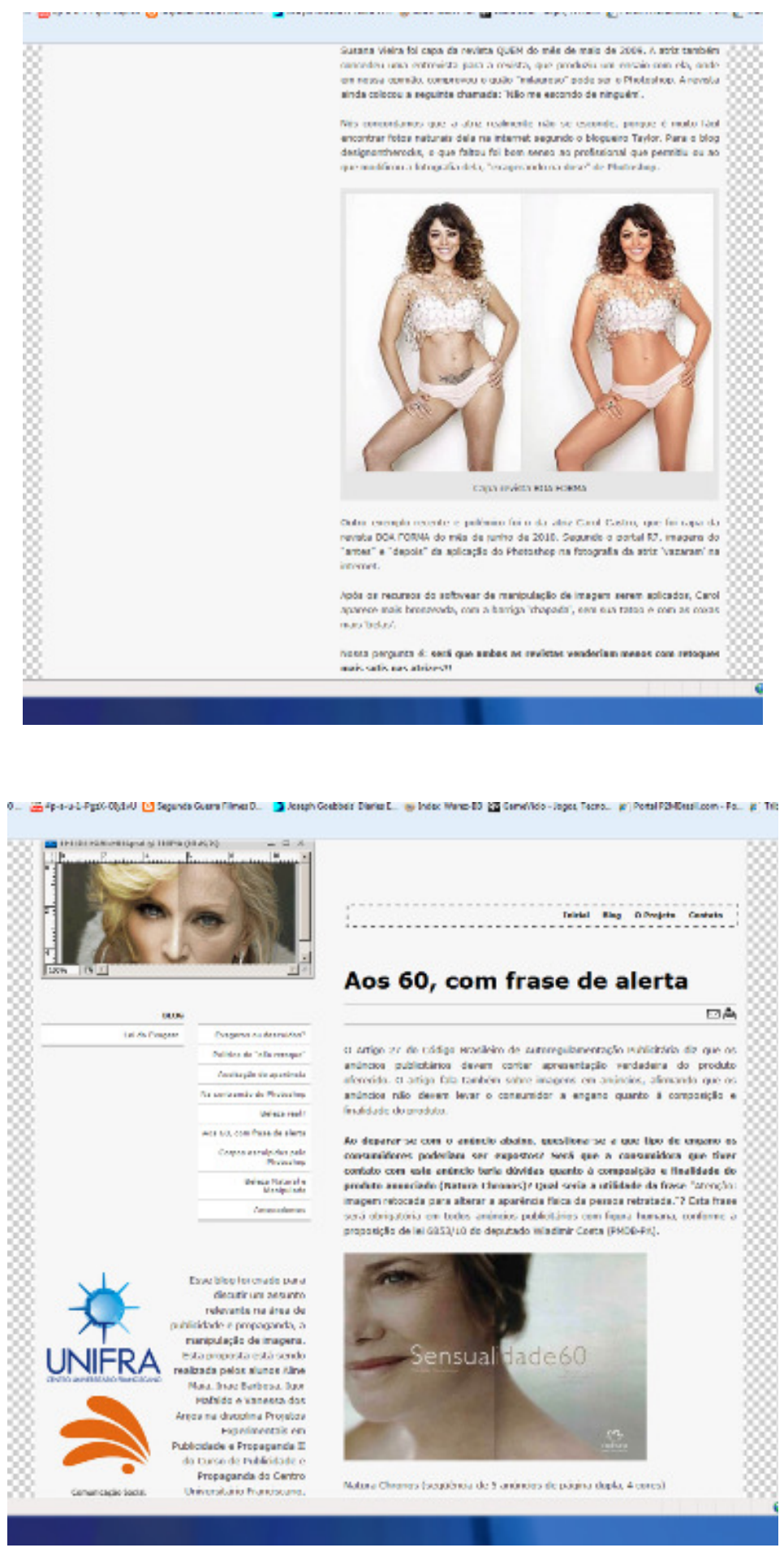


\section{Monografias Ambientais}

REMOA

(Revista Eletrônica do Curso de Especialização em Educação Ambiental da UFSM)

Anexo 13 e 14
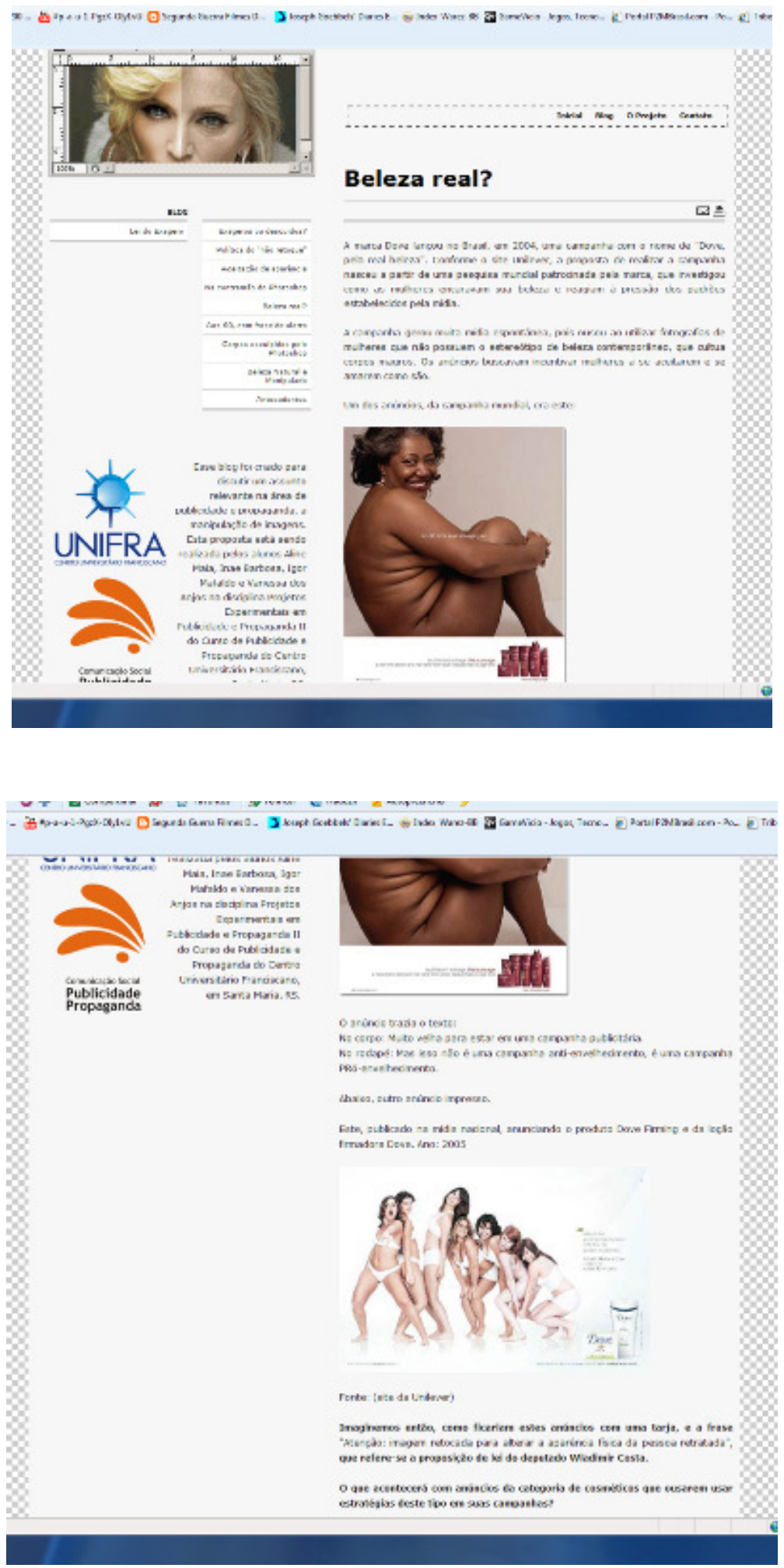


\section{Monografias Ambientais}

REMOA

(Revista Eletrônica do Curso de Especialização em Educação Ambiental da UFSM)

Anexo 15 e 16
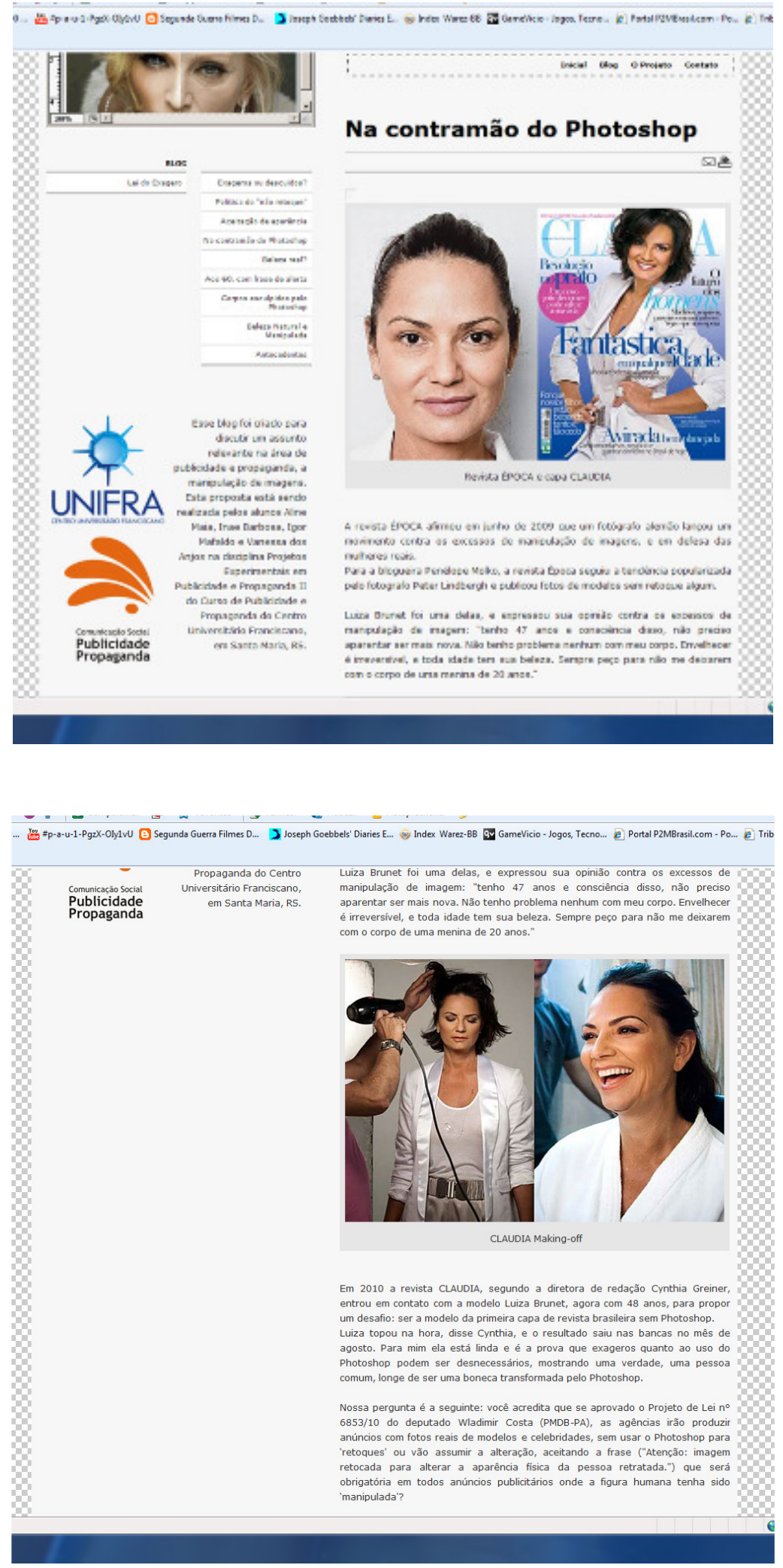


\section{Monografias Ambientais}

REMOA

(Revista Eletrônica do Curso de Especialização em Educação Ambiental da UFSM)

Anexo 17 e 18
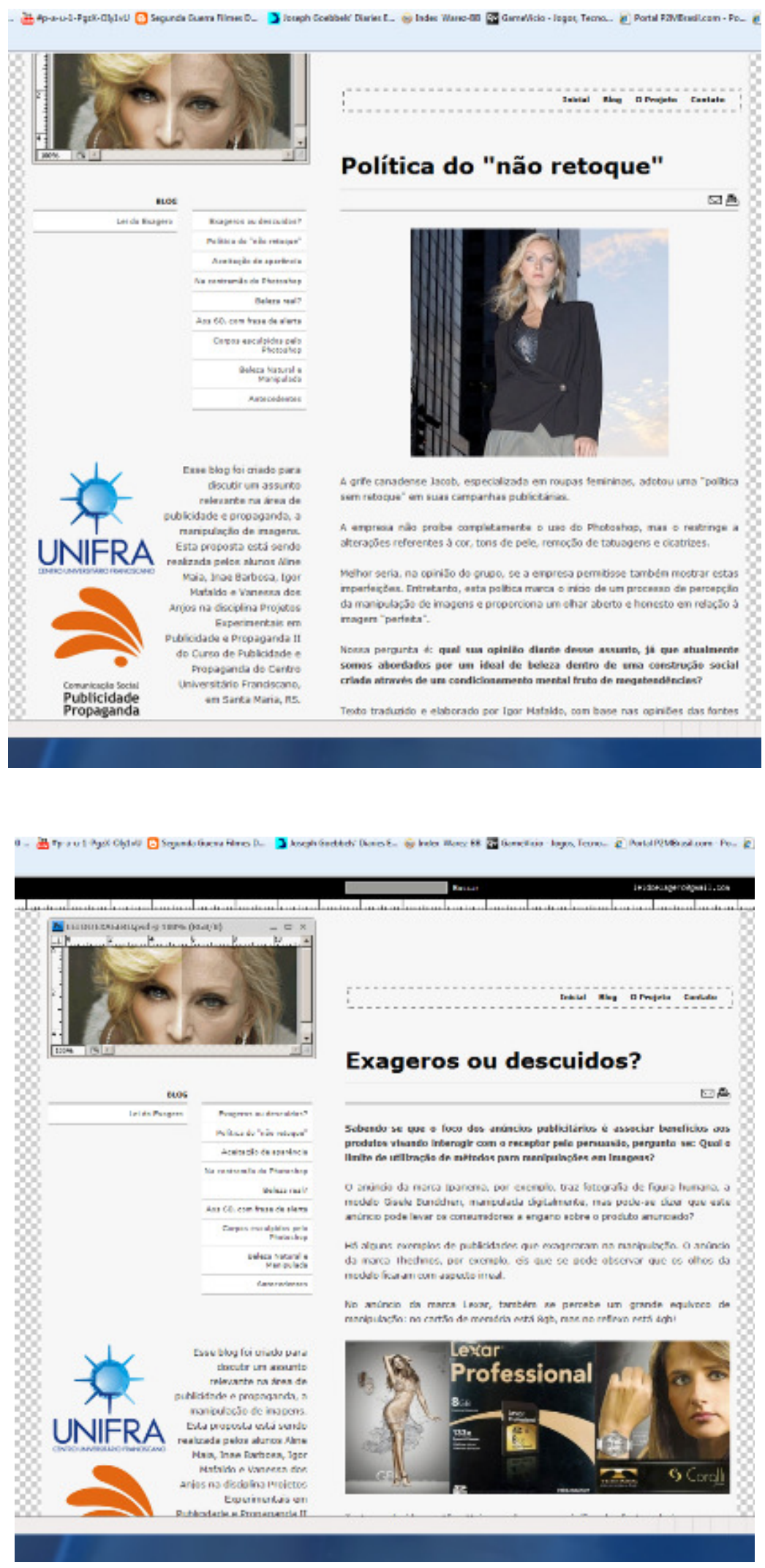
MAIA et al., vol.(3), $n^{\circ} 3$, p.482-513, 2011

513

Monografias Ambientais

(Revista Eletrônica do Curso de Especialização em Educação Ambiental da UFSM)

Anexo 19

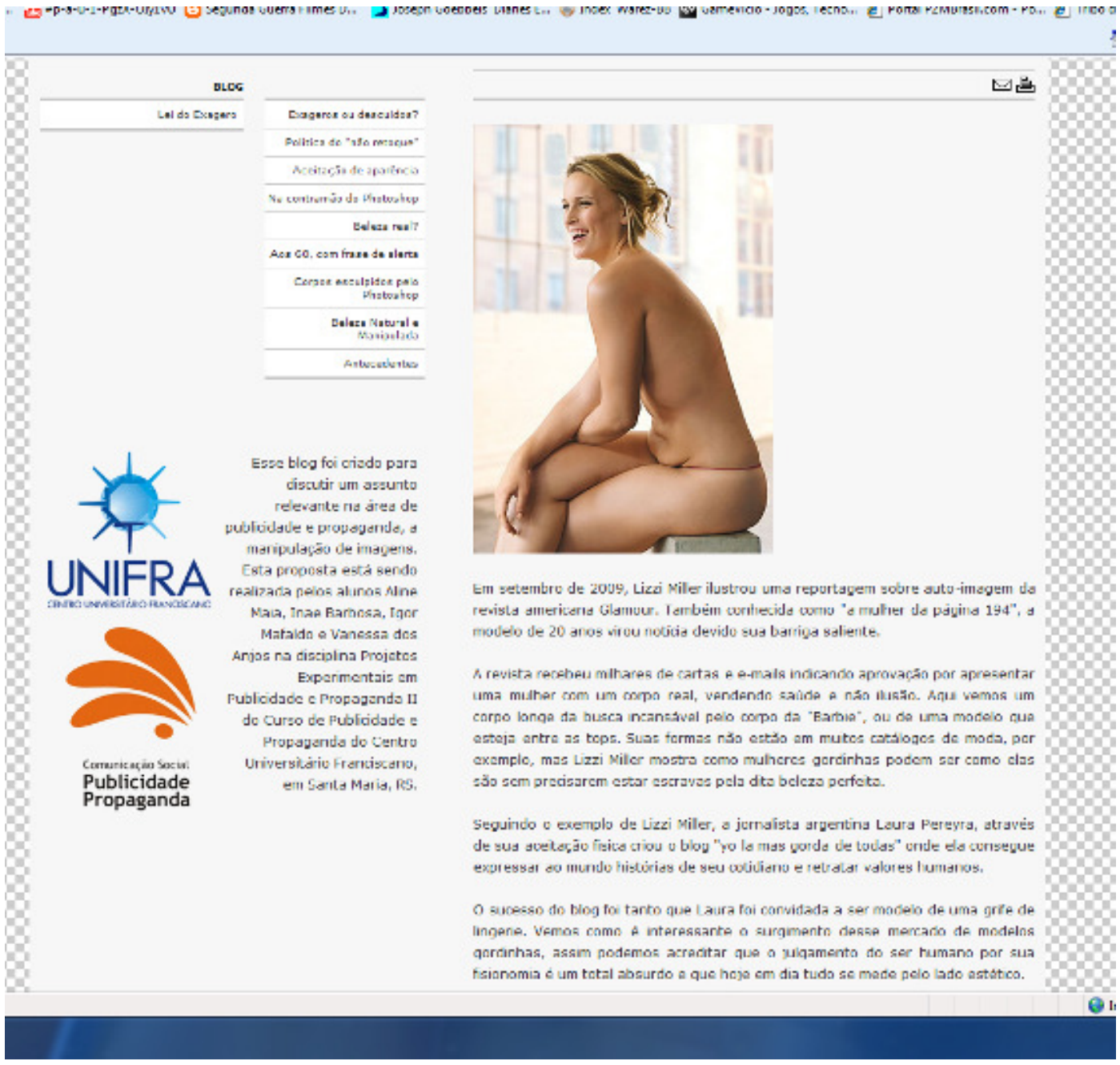

